\title{
Outcome of health education on HIV/AIDS knowledge, attitude and risky sexual behavior among commercial motorcyclists in Osogbo, Nigeria
}

\author{
Olarewaju Sunday Olakunle ${ }^{1 *}$, Bamidele James ${ }^{1,2}$, Odu Olusola ${ }^{1,2}$, Olarewaju Oluwatoyin ${ }^{3,4}$
}

\author{
${ }^{1}$ Department of Community Medicine, LAUTECH College of Health Sciences, Ogbomoso, Oyo-State, Nigeria \\ ${ }^{2}$ Department of Community Medicine, Ekiti State University, Ado-Ekiti, Nigeria \\ ${ }^{3}$ Catholic Action Committee on AIDS, Gaduwa Estate, Abuja, Nigeria \\ ${ }^{4}$ Department of Medical Microbiology, Lautech University of Technology, Osogbo, Nigeria
}

Received: 25 August 2015

Revised: 28 August 2015

Accepted: 09 October 2015

\section{*Correspondence: \\ Dr. Olarewaju Sunday Olakunle, \\ E-mail: oolarewaju7@gmail.com}

Copyright: (c) the author(s), publisher and licensee Medip Academy. This is an open-access article distributed under the terms of the Creative Commons Attribution Non-Commercial License, which permits unrestricted non-commercial use, distribution, and reproduction in any medium, provided the original work is properly cited.

\begin{abstract}
Background: Commercial motorcyclists in Nigeria are usually males within the reproductive age group and at risk of HIV/AIDS due to sub-optimal information on the cause and prevention as well as defective perception on HIV/AIDs, hence the need for continuous health education among this occupational group. Objective: To determine the effect of health education on knowledge, perception and risky sexual practices on HIV/AIDS among commercial motorcyclist in Osogbo, Osun state.

Methods: A cross sectional descriptive survey with an intervention component was conducted in three stages between November, 2007 and June, 2008. One hundred and fifty respondents from both study and control groups were selected using a multi-stage sampling technique and interviewed with a pre-tested semi-structured questionnaire. The post-intervention stage was done 6 months later.

Results: At post-intervention, study group (i.e. intervention group) exhibited a greater knowledge on correct methods of prevention and transmission of HIV/AIDS $(\mathrm{P}<0.05)$. Similarly, there was significant improvement in their attitudes towards people living with HIV/AIDS among respondents in the study group $(\mathrm{P}<0.05)$. In addition, the number of respondents having multi-sexual partners decreased from $24.7 \%$ pre-intervention to $14.2 \%$ six months post intervention. $(\mathrm{P}=0.01)$.

Conclusions: This study has shown that health education can be effective in bridging the knowledge gap of HIV/AIDS among commercial motorcyclists. It is therefore recommended that continuous health education programmes on HIV/AIDS by relevant stakeholders be established for this category of occupation.
\end{abstract}

Keywords: Commercial motorcyclists, Health education, HIV/AIDS

\section{INTRODUCTION}

Acquired Immune Deficiency Syndrome (AIDS) is a global health problem. AIDS is the fourth largest cause of death globally and the leading cause of death in Africa. ${ }^{1}$
Nigeria carries the second heaviest burden of HIV in Africa. AIDS was first reported in Nigeria in 1986, and as at December 2011, 3459363 people now live with HIV with an estimated 1449166 require ARV, 388864 new infections occurred in the year ended 2011 and records 
show 217148 AIDS related deaths. ${ }^{2}$ In addition, about 2193745 orphans are living with HIV/AIDS. ${ }^{3}$ A survey among commercial motorcyclist in year 2003 found the baseline prevalence of $\mathrm{HIV}-1$ to be $14 \%$ in Nigeria. ${ }^{4}$ Majority of commercial motorcycle riders are mostly young adult males found within the ages of 20-59 years which represents largely the economically productive segment of Nigerian population. ${ }^{5}$ This age group is at greatest risk of HIV infection. ${ }^{5}$

An in depth assessment of out-of-school youths identified motorcyclist as a high risk group to having HIV infection. ${ }^{6}$ It is important to mention that these categories of individuals often offer free rides in exchange for sexual favors and their trust of sexual partners was cited as the most pertinent reason for non-use of condoms. They sometimes patronize commercial sex workers who have a high prevalence $(30-40 \%)$ of HIV/AIDs. ${ }^{7}$ The commercial motorcyclist serve as interface between this high-risk group and the community. Since $80 \%$ of the infection is acquired heterosexually in Africa changing sexual behavior among this group will have significant impact on the control of infection. In addition, a great number of these commercial riders are illiterates thereby limiting their access to correct information on HIV and understanding the health messages and consequent use of preventive measures. ${ }^{5}$

This low level of literacy rate and limited access to information also contributes to low utilization of our Sexually Transmitted Infections treatment facilities within the health facilities. Likewise, this occupational group operated under the influence of substances such as alcohol, tobacco, marijuana while at work etc. ${ }^{8}$ It has been documented that excessive consumption of these substances is independently associated with sexual behavior involving greater risk of HIV infection. ${ }^{8}$ The use of substances make it psychologically easier to engage in prostitution. Motorcyclists also have access to disposable incomes at a younger age which is often used to engage in high sexual activity. However, previous studies done in Benin City, South Western Nigeria seems to show suboptimal information on mode of HIV transmissions and preventions about this new group of transporters in Nigeria. ${ }^{8}$ Sexuality education among this professional group will help in influencing important risky sexual behavior such as delay of sexual initiation, reducing the number of sexual partners and increasing use of condom. It will also help in improving their knowledge of causation and prevention of HIV/AIDS and STDS which will assist in reducing the incidence of HIV/AIDS and other STDS among this group within our society thereby necessitating the need for this study.

\section{METHODS}

\section{Study area}

The study was conducted in osogbo town. Osogbo is presently the capital of Osun state, Nigeria and was carved out from old Oyo state in 1991. It is situated on latitude 7.47 North of the equator and longitude 4.33 East of the Greenwich meridian. The city is located at the geographical center of Osun-state and is about $48 \mathrm{~km}$ from Ife, $32 \mathrm{~km}$ from Ilesa, $48 \mathrm{~km}$ from Iwo and about $48 \mathrm{~km}$ from Ikire. Osogbo has a network of motorable roads which makes it accessible to all the towns mentioned as well as other towns and villages. Commercial motorcyclists were located in 6 motorcycle parks namely: Oja Oba, Isale Osun, Oke baale, Dada Estate, Okefia and Olaiya garage.

The control group was commercial motorcyclists located in Ede. The town is located 20 kilometers away from Osogbo and has a geographical area of about 40 square kilometer and a population of about 490000 with an annual rainfall of about of 55-57 inches. Majorities are predominantly Muslim but some are Christians while others practice traditional religion. The town is similar in many socio-demographic and cultural aspects to Osogbo town. Commercial motorcyclists were also located Akala Park, Orita Oloki Park, Olukolo Park and Sekona Park.

\section{Study population}

The study population comprises of all registered commercial motorcyclists across 12 terminals in Osogbo and 10 terminals in Ede Township.

\section{Study design}

A cross-sectional descriptive survey with an intervention stage (health education component) given to the study group.

\section{Sample size estimation}

The Corlien method ${ }^{9}$ (for comparative studies) was used to calculate the sample size i.e.

$$
\mathrm{N}=\frac{(\mathrm{U}+\mathrm{V})^{2}(\mathrm{P} 1(1-\mathrm{P} 1)+\mathrm{P} 2(1-\mathrm{P} 2)}{(\mathrm{P} 1-\mathrm{P} 2)^{2}}
$$

$\mathrm{N}=$ Minimum sample size

$\mathrm{P} 1$ = Expected prevalence of sexual risk behavior after intervention $=81 \%$

$\mathrm{P} 2=$ Prevalence of risky behavior from previous studies ${ }^{5}$ $=66 \%$

$\mathrm{V}=$ Percentage point of the normal distribution, corresponding to the two sided significant level of $5 \%$ $(\mathrm{V}=1.96)$

$\mathrm{U}=$ One sided percentage point of the normal distribution where the power equals the probability of finding a significant result using the power of $80 \%(\mathrm{u}=0.84)$ 


$$
\begin{gathered}
\mathrm{N}=\frac{(1.96+0.84)^{2}(0.81(1-0.81)+0.66(1-0.66)}{(0.15)^{2}} \\
\mathrm{~N}=\frac{(7.84)(0.154+0.224)}{0.0225}
\end{gathered}
$$

$\mathrm{N}=131.8=132$

\section{Correcting for non-response}

$\mathrm{Nc}=\mathrm{N}+(2 / \mathrm{P} 1-\mathrm{P} 2)=132+14=146$ as the minimum sample size required.

However, 150 Commercial motorcyclists were deliberately recruited for the study group and an equal number of Commercial motorcyclists were also recruited for the Control group.

\section{Sampling technique}

Multi-stage sampling technique was used to sample respondents of commercial motorcyclists registered with the central union after consent was obtained. At the time of study there were 2100 and 1595 registered members distributed among the 22 commercial motorcyclists' terminals who constituted the study population (12 terminals in Osogbo and 10 terminals in Ede).

The list of the terminals formed the primary sampling unit, while the registered motorcyclists formed secondary sampling unit. Based on this, 6 out of 10 terminals were chosen at random for the study group while 5 out of 10 terminals chosen at random for the control group.

The list of registered motorcyclists in their respective terminals was used as a sampling frame to select the sample-size. Respondents were selected for both the cases and control groups using a sampling interval.

In each of the selected terminals, structured closed ended and interviewer administered questionnaires were used to collect information on socio-demographic characteristics, knowledge, perception and risky sexual behavior on HIV/AIDS. Interviewers were trained before administering the questionnaire.

Questionnaire was pre-tested among commercial motorcyclists in Ilesa, a town similar to Osogbo. This was done to ensure validity and reliability of the instrument. The pre-tested questionnaire was analyzed and necessary modifications effected. The questionnaires were both interviewer and self-administered. Selfadministration was done for those who could read and write while interview administered was done using six recruited and trained research assistants (final year medical students who have just completed their final posting in community medicine) for those who couldn't read nor write. Before each motorcyclist completed the questionnaire, purpose of the study was explained collectively and individually. To ensure confidentiality, no names were recorded. Permission was also sought and obtained from the chairmen of association of commercial motorcyclists from all the selected terminals.

Baseline information were collected from both study and control groups in the first two weeks and last two weeks of November, 2007 on 300 commercial motorcyclists, 150 in Osogbo (cases) and 150 in Ede (control group) respectively. Based on the baseline findings, area of misconception, knowledge gap, attitude and risky sexual practices were noted and used in constructing health education messages. Six weekly health educations were implemented among commercial motorcyclists in Osogbo by the main investigator (community physician) assisted by 6 recruited/trained research assistant in conjunction with health educator specialist at Osogbo town hall.

Topics to be discussed were assigned before hand to each person to allow adequate preparation and same topics were handled by same individuals during all the sessions to ensure uniformity of messages. Materials used for the health education session included pamphlets (that have been previously designed and tested by United Nations Fund for Population activities, and are relevant to HIV education among at risk groups in the society), relevant posters (obtained from Osun state ministry of health and UNFPA which were pasted on the walls) and power-point projections with relevant pictures and diagrams (were referred to for illustrations).

The time schedule for health education was drawn in collaboration with the chairmen of the commercial motorcyclist association in respective terminals and the selected members. A day of the week from Monday to Saturday was assigned for training each group. Participants were grouped into 4 sets based on the number selected from each terminal. Six days in a week was used in training each set of group. Each training session lasted for about 30 minutes and was conducted in the morning hours between 10:30am and 11:00am. Each set of group had six health education sessions. This makes the health education activities convenient for each participant and the facilitators and for better understanding. All the invited 150 participants participated in the training. Names of participant with respective terminal and phone numbers were taken for proper follow-up.

Evaluation was carried out 6 months later by the researcher using the same research tool used during the pre-intervention stages to determine effect of health education intervention on their indulgence in risky behaviors, knowledge of HIV transmission and prevention, perception towards HIV/AIDS. For ethical reasons, the control group also benefited from the health education after collection of post intervention data in July, 2008 using same education materials. A feedback of the results of the study was discussed with the chairman of the association. Four commercial motorcyclists (2\%) 
were lost to follow up, therefore 148 commercial motorcyclists in both study and control groups filled the questionnaire at post-evaluation.

Baseline and end line data were evaluated using Statistical Package for Social Sciences (SPSS) version 14. Frequency distribution tables were generated while cross-tabulation and test statistics like the t-test for testing the significance of an observed difference between means of two groups, the Pearson's Chi-square (for comparing proportions of events occurring in two or more groups of categorical data) and McNemars Chi square test (to compare proportions of paired observations) were applied in detecting statistical associations. The $\mathrm{P}$ values were generated and the significant level set at level less than $0.05(\mathrm{P}<0.05)$.

\section{RESULTS}

\section{Baseline comparison}

At baseline, the control and experimental groups are matched.

\section{Demographic data}

There was no statistical difference in the mean age, tribe, religion, educational and marital status of respondents in the experimental and control groups. For example, the mean age of respondents is $33.1 \pm 9.6$ years with a range of 18-56 years in the study and $32.3 \pm 9.0$ years with a range of 17-57 years in the control. The major ethnic group among the respondents in both study and control groups was Yoruba with $140(93.3 \%)$ in the study and $141(93.3 \%$ in control) groups respectively. Majority of the respondents $99(66 \%)$ of the study and $114(76 \%)$ of the control groups were Muslims, while $51(34.0 \%)$ of the study group and $36(24.0 \%)$ of the control group were Christians. Also, most of the respondents 79 (52.7\%) of the study group and $167(55.7 \%)$ of the control group had secondary education. Most of the respondents 110 $(73.3 \%)$ of both the study group and $110(73.3 \%)$ of control group were married while $40(26.7 \%)$ of both the study group and control groups were singles (Table 1).

Table 1: Showing the knowledge about the disease caused by dog bite ( $\mathrm{N}=111)$.

\begin{tabular}{|c|c|c|c|c|c|c|c|}
\hline \multirow{2}{*}{$\begin{array}{l}\text { Socio-demographic } \\
\text { characteristics }\end{array}$} & \multicolumn{2}{|c|}{$\begin{array}{l}\text { Study } \\
\text { group }\end{array}$} & \multicolumn{2}{|c|}{$\begin{array}{l}\text { Control } \\
\text { group }\end{array}$} & \multicolumn{2}{|c|}{ Total } & \multirow{2}{*}{$\begin{array}{l}\text { Statistics } \\
\mathbf{P}<0.05\end{array}$} \\
\hline & $\mathbf{N}$ & $\%$ & $\mathbf{N}$ & $\%$ & $\mathbf{N}$ & $\%$ & \\
\hline \multicolumn{8}{|l|}{ Age group (years) } \\
\hline 15.24 & 21 & 14.0 & 27 & 18.0 & 48 & 16.0 & \multirow{6}{*}{0.48} \\
\hline $25-34$ & 72 & 48.0 & 66 & 44.0 & 138 & 46.0 & \\
\hline $35-44$ & 34 & 22.7 & 38 & 25.3 & 72 & 24.0 & \\
\hline $45-54$ & 18 & 12.0 & 15 & 10.0 & 33 & 11.0 & \\
\hline$>55$ & 5 & 3.3 & 4 & 2.7 & 9 & 3.0 & \\
\hline Total & 150 & 100 & 150 & 100 & 300 & 100 & \\
\hline \multicolumn{7}{|l|}{ Tribe } & \multirow{4}{*}{0.813} \\
\hline Yoruba & 140 & 93.3 & 141 & 94.0 & 281 & 93.7 & \\
\hline Others (Hausa, Ibo) & 10 & 6.7 & 9 & 6.0 & 19 & 6.3 & \\
\hline Total & 150 & 100 & 150 & 100 & 300 & 100 & \\
\hline \multicolumn{7}{|l|}{ Religion } & \multirow{4}{*}{0.06} \\
\hline Islam & 99 & 66 & 114 & 76 & 213 & 71 & \\
\hline Christianity & 51 & 34 & 36 & 24 & 87 & 29 & \\
\hline Total & 150 & 100 & 150 & 100 & 300 & 100 & \\
\hline \multicolumn{7}{|l|}{ Educational status } & \multirow{6}{*}{0.77} \\
\hline No education & 7 & 4.7 & 6 & 4.0 & 13 & 4.3 & \\
\hline Primary education & 53 & 35.3 & 47 & 31.3 & 100 & 33.3 & \\
\hline Secondary education & 79 & 52.7 & 88 & 58.7 & 167 & 55.7 & \\
\hline Post-secondary education & 11 & 7.3 & 9 & 6.0 & 20 & 6.7 & \\
\hline Total & 150 & 100 & 150 & 100 & 300 & 0 & \\
\hline \multicolumn{7}{|l|}{ Marital status } & \multirow{4}{*}{1.00} \\
\hline Single & 40 & 26.7 & 40 & 26.7 & 80 & 26.7 & \\
\hline Married (Ever/Current) & 110 & 73.3 & 110 & 73.3 & 220 & 73.3 & \\
\hline Total & 150 & 100 & 150 & 100 & 300 & 100 & \\
\hline \multicolumn{7}{|l|}{ Number of wives } & \multirow{4}{*}{0.07} \\
\hline One & 93 & 84.5 & 84 & 76.4 & 177 & 80.5 & \\
\hline Two or more & 17 & 15.5 & 26 & 23.6 & 43 & 19.5 & \\
\hline Total & 110 & 100 & 110 & 100 & 220 & 100 & \\
\hline
\end{tabular}




\section{Knowledge on HIV symptoms}

Also there was no significant difference in the knowledge on HIV symptoms between both groups $(\mathrm{P}>0.05)$. Majority of the respondents in the study and control groups were aware of weight loss as a major symptom of someone infected with HIV/AIDS as mentioned by 105 $(70 \%)$ of the study and $126(84 \%)$ of the control. There was also no statistical difference in knowledge in both the study and the control group on other symptoms such as chronic fever, skin rashes, headache, weakness and chronic diarrhea $(\mathrm{P}>0.05)$ (Table 2$)$.

Table 2: Respondents knowledge on symptoms of HIV/AIDS (multiple responses allowed).

\begin{tabular}{|c|c|c|c|c|c|}
\hline \multirow[t]{2}{*}{$\begin{array}{l}\text { Symptoms of } \\
\text { AIDS }\end{array}$} & \multicolumn{2}{|c|}{$\begin{array}{l}\text { Study } \\
\text { group } \\
(\mathrm{n}=150)\end{array}$} & \multicolumn{2}{|c|}{$\begin{array}{l}\text { Control } \\
\text { group } \\
(\mathrm{n}=150)\end{array}$} & \multirow[t]{2}{*}{$\begin{array}{l}\mathbf{P} \\
\text { value }\end{array}$} \\
\hline & Freq & $\%$ & Freq & $\%$ & \\
\hline Weight loss & 105 & 70 & 126 & 84.0 & 0.07 \\
\hline Chronic diarrhea & 26 & 17.3 & 18 & 12.0 & 0.19 \\
\hline Chronic fever & 14 & 9.3 & 15 & 10.0 & 0.19 \\
\hline Cough & 4 & 2.6 & 6 & 4.0 & 0.5 \\
\hline Skin rashes & 8 & 5.3 & 2 & 1.3 & 0.05 \\
\hline Headache & 8 & 5.3 & 5 & 3.3 & 0.4 \\
\hline Weakness & 10 & 6.7 & 19 & 12.7 & 0.08 \\
\hline
\end{tabular}

\section{Knowledge on preventive measures}

Out of the 150 respondents in the study and control groups, $42(28 \%)$ and $44(29.3 \%)$ were aware abstinence as a preventive measure, $66(44 \%)$ and $71(47.3 \%)$ of faithfulness to one's partner, $57(38 \%)$ and $71(47.3 \%)$ of condom use, $3(2 \%)$ and $5(3.3 \%)$ of blood screening, 26 $(17.3 \%)$ and $40(26.7 \%)$ of sterilizing clipper in both study and control groups respectively. $1(0.7 \%)$ in the control group is of the opinion of isolation of affected patient as a means of preventive measure while $2(1.3 \%)$ of the study group beliefs that voluntary counseling and testing before marriage as a means of prevention of HIV/AIDS. There is no statistical difference related to the modes of prevention between the study groups and the control groups $(\mathrm{P}>0.05)$ (Table 3$)$.

Table 3: Knowledge of respondents on preventive measures of HIV/AIDS (Multiple response allowed).

\begin{tabular}{|llllll|}
\hline $\begin{array}{l}\text { Mode of } \\
\text { preventive } \\
\text { measures }\end{array}$ & $\begin{array}{l}\text { Study } \\
\text { group } \\
(\mathbf{n = 1 5 0 )}\end{array}$ & $\begin{array}{l}\text { Control } \\
\text { group } \\
(\mathbf{n = 1 5 0 )}\end{array}$ & $\begin{array}{l}\text { P } \\
\text { value }\end{array}$ \\
\hline Abstinence & 42 & 28.0 & 44 & 29.3 & 0.8 \\
Faithfulness & 66 & 44.0 & 71 & 47.3 & 0.6 \\
Condom use & 57 & 38.0 & 71 & 47.3 & 2.7 \\
Blood screening & 3 & 2.0 & 5 & 3.3 & 0.5 \\
Sterilize clipper & 29 & 19.3 & 40 & 26.7 & 2.8 \\
Isolation of & & & & & \\
infected person & 0 & 0.0 & 1 & 0.7 & 0.3 \\
VCT & 2 & 1.3 & 0 & 0.0 & 0.2 \\
\hline
\end{tabular}

\section{Attitude towards HIV/AIDS}

Out of the 150 respondents in both study and control groups, $51(34 \%)$ and $53(35.3 \%)$ cannot carry an infected male friend on the motorcycle, 37 (24.7\%) and $114(76.0 \%)$ cannot buy food from infected food seller, $105(70 \%)$ and $99(66 \%)$ cannot eat with an infected person, $84(56 \%)$ and $78(52 \%)$ cannot sleep in the same room with infected person, $49(32.7 \%)$ and $59(39.3 \%)$ cannot continue friendship with an infected partner in both study and control groups respectively. There is no statistical difference in both groups $(\mathrm{P}>0.05)$ (Table 4).

Table 4: Respondents attitude towards PLWA.

\begin{tabular}{|c|c|c|c|c|c|c|c|c|c|}
\hline \multirow{3}{*}{ Attitude } & \multicolumn{4}{|c|}{ Study group $(\mathrm{n}=\mathbf{1 5 0})$} & \multicolumn{4}{|c|}{ Control group $(n=150)$} & \multirow{3}{*}{$\begin{array}{l}P \\
\text { value }\end{array}$} \\
\hline & \multicolumn{2}{|c|}{ Freq } & \multicolumn{2}{|c|}{ Freq } & \multicolumn{2}{|c|}{ Freq } & \multicolumn{2}{|c|}{ Freq } & \\
\hline & Yes & $(\%)$ & No & $(\%)$ & Yes & $(\%)$ & No & $(\%)$ & \\
\hline Carrying an infected male friend on motorcycle & 99 & 66.0 & 51 & 34.0 & 97 & 64.7 & 53 & 35.3 & 0.8 \\
\hline Buying food from an infected food seller & 37 & 24.7 & 113 & 5.3 & 36 & 24.0 & 114 & 6.0 & 0.9 \\
\hline Eating with an infected person & 45 & 30.0 & 105 & 70.0 & 51 & 34.0 & 99 & 6.0 & 0.45 \\
\hline Sleeping in the same room with infected person & 66 & 44.0 & 84 & 56.0 & 72 & 48.0 & 78 & 52.0 & 0.49 \\
\hline Continuation of friendship with infected person & 101 & 67.3 & 49 & 32.7 & 91 & 60.7 & 59 & 39.3 & 0.23 \\
\hline
\end{tabular}

\section{Sexual behavior}

There was no statistical difference in the patronage of commercial partners between the study and the control groups as shown in Figure $1(\mathrm{P}=0.5)$.

\section{End-line comparison}

Knowledge on HIV symptoms

In the study group, levels of knowledge of respondents on HIV symptoms increased after intervention and the 
observed differences were statistically significant $(\mathrm{P}<0.05)$ (Table 5).

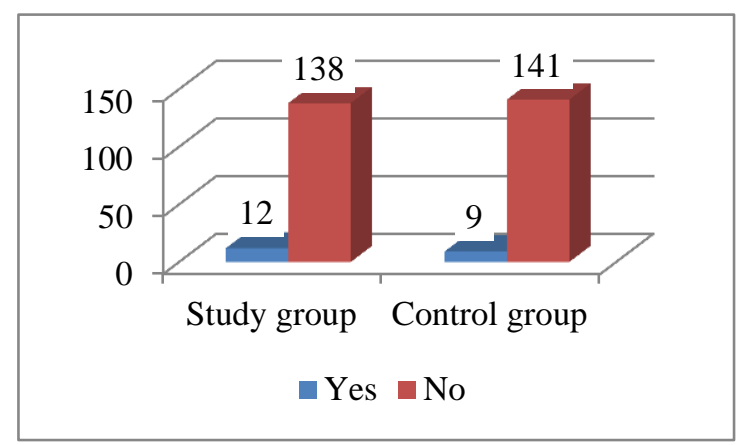

Figure 1: Practices related to HIV/AIDS among respondents (Respondents patronage of commercial partner in last 6 months).

Knowledge on preventive measures

Post intervention, there was an improvement in the knowledge of respondents in the study group, about ways in which HIV/AIDS can be prevented - when compared the differences were found to be statistically significant $(\mathrm{P}<0.05)$ (Table 6)

\section{Attitude towards HIV/AIDS}

There was a statistical significant improvement in the attitude of respondents towards PLWA more of the respondents in the study group $(\mathrm{P}<0.05)$ while those in control group showed no statistically significant difference in the attitude of the respondents in the control group towards people living with HIV/AIDS $(\mathrm{P}>0.05)$. (Table 7).

\section{Sexual behavioral practices}

Among the respondents in the study group, the patronage of commercial partners reduces from $8 \%$ to $2 \%$. This reduction is statistically significant in the study group. $(\mathrm{P}<0.05)$ while in the control group, there was an increase from $6.0 \%$ to $9.5 \%$ with no significant difference as shown in table $30(\mathrm{P}>0.05)$ (Table 8$)$.

Table 5: Respondents knowledge on symptoms of HIV/AIDS (Multiple responses allowed).

\begin{tabular}{|c|c|c|c|c|c|c|c|c|c|c|}
\hline \multirow{3}{*}{$\begin{array}{l}\text { Symptoms of } \\
\text { HIV/AIDS }\end{array}$} & \multicolumn{4}{|c|}{ Study group } & \multirow{3}{*}{$\mathbf{P}$} & \multicolumn{4}{|c|}{ Control group } & \multirow{3}{*}{$\mathbf{P}$} \\
\hline & \multicolumn{2}{|c|}{$\begin{array}{l}\text { Pre-intervention } \\
(n=150)\end{array}$} & \multicolumn{2}{|c|}{$\begin{array}{l}\text { Post-intervention } \\
(n=148)\end{array}$} & & \multicolumn{2}{|c|}{$\begin{array}{l}\text { Pre-intervention } \\
(n=150)\end{array}$} & \multicolumn{2}{|c|}{$\begin{array}{l}\text { Post-intervention } \\
(n=148)\end{array}$} & \\
\hline & Freq & $\%$ & Freq & $\%$ & & Freq & $\%$ & Freq & $\%$ & \\
\hline Weight loss & 105 & 70.0 & 132 & 89.2 & 0.00 & 126 & 84.0 & 116 & 78.3 & 0.07 \\
\hline Chronic diarrhoea & 26 & 17.3 & 58 & 39.2 & 0.00 & 18 & 12.0 & 12 & 8.1 & 0.05 \\
\hline Chronic fever & 14 & 9.3 & 62 & 41.9 & 0.00 & 15 & 10.0 & 13 & 8.7 & 0.32 \\
\hline Cough & 4 & 2.6 & 40 & 27.0 & 0.00 & 6 & 4.0 & 3 & 2.0 & 0.06 \\
\hline Skin rashes & 8 & 5.3 & 24 & 16.2 & 0.00 & 2 & 1.3 & 3 & 2.0 & 0.64 \\
\hline Headache & 8 & 5.3 & 1 & 0.67 & 0.00 & 5 & 3.3 & 3 & 2.0 & 0.49 \\
\hline Weakness & 10 & 6.3 & 2 & 1.35 & 0.00 & 19 & 12.7 & 11 & 7.4 & 0.13 \\
\hline
\end{tabular}

Table 6: Knowledge on preventive measures; Respondents knowledge about ways in which HIV/AIDS can be prevented (Multiple responses allowed).

\begin{tabular}{|c|c|c|c|c|c|c|c|c|c|c|}
\hline \multirow{3}{*}{$\begin{array}{l}\text { Mode of } \\
\text { prevention }\end{array}$} & \multicolumn{4}{|c|}{ Study group } & \multirow{3}{*}{$P<0.05$} & \multicolumn{4}{|c|}{ Control group } & \multirow{3}{*}{$P<0.05$} \\
\hline & \multicolumn{2}{|c|}{$\begin{array}{l}\text { Pre-intervention } \\
(n=150)\end{array}$} & \multicolumn{2}{|c|}{$\begin{array}{l}\text { Post-intervention } \\
(n=148)\end{array}$} & & \multicolumn{2}{|c|}{$\begin{array}{l}\text { Pre-intervention } \\
(\mathrm{n}=150)\end{array}$} & \multicolumn{2}{|c|}{$\begin{array}{l}\text { Post-intervention } \\
(\mathrm{n}=\mathbf{1 4 8})\end{array}$} & \\
\hline & Freq & $\%$ & Freq & $\%$ & & Freq & $\%$ & Freq & $\%$ & \\
\hline Abstinence & 42 & 28.0 & 64 & 43.2 & 0.00 & 44 & 29.3 & 50 & 33.8 & 0.07 \\
\hline Faithfulness & 66 & 44.0 & 96 & 64.8 & 0.00 & 71 & 47.3 & 77 & 52.0 & 0.64 \\
\hline Condom use & 57 & 38.0 & 96 & 64.8 & 0.00 & 71 & 47.3 & 72 & 48.6 & 0.32 \\
\hline Sterilize clipper & 29 & 19.3 & 80 & 54.1 & 0.00 & 40 & 26.7 & 45 & 30.4 & 0.47 \\
\hline $\begin{array}{l}\text { Isolation of } \\
\text { infected person }\end{array}$ & 11 & 7.3 & 0 & 0.0 & 0.00 & 9 & 6.0 & 13 & 8.78 & 0.36 \\
\hline VCT & 5 & 3.3 & 17 & 11.5 & 0.00 & 19 & 12.7 & 5 & 3.3 & 0.46 \\
\hline
\end{tabular}


Table 7: Attitude of respondents in the study group towards PLWA.

\begin{tabular}{|c|c|c|c|c|c|c|c|c|c|c|}
\hline \multirow{3}{*}{ Attitude } & \multicolumn{4}{|c|}{ Study group } & \multirow{3}{*}{$P<0.05$} & \multicolumn{4}{|c|}{ Control group } & \multirow{3}{*}{$P<0.05$} \\
\hline & \multicolumn{2}{|c|}{$\begin{array}{l}\text { Pre-intervention } \\
(\mathbf{n}=150)\end{array}$} & \multicolumn{2}{|c|}{$\begin{array}{l}\text { Post-intervention } \\
(\mathrm{n}=\mathbf{1 4 8})\end{array}$} & & \multicolumn{2}{|c|}{$\begin{array}{l}\text { Pre-intervention } \\
(\mathrm{n}=150)\end{array}$} & \multicolumn{2}{|c|}{$\begin{array}{l}\text { Post-intervention } \\
(\mathrm{n}=148)\end{array}$} & \\
\hline & Freq & $\%$ & Freq & $\%$ & & Freq & $\%$ & Freq & $\%$ & \\
\hline $\begin{array}{l}\text { Avoid carrying infected } \\
\text { male friend on motorcycle }\end{array}$ & 95 & 63.3 & 20 & 13.5 & 0.00 & 107 & 71.3 & 119 & 80.4 & 0.06 \\
\hline $\begin{array}{l}\text { Avoid buying food from } \\
\text { infected food seller }\end{array}$ & 73 & 48.7 & 90 & 60.8 & 0.02 & 99 & 66.0 & 105 & 70.9 & 0.36 \\
\hline $\begin{array}{l}\text { Avoid eating with infected } \\
\text { person }\end{array}$ & 66 & 44.0 & 98 & 66.2 & 0.00 & 81 & 54.0 & 88 & 59.5 & 0.34 \\
\hline $\begin{array}{l}\text { Avoid sleeping in the same } \\
\text { room with infected person }\end{array}$ & 16 & 10.7 & 80 & 54.1 & 0.00 & 11 & 7.3 & 13 & 8.8 & 0.65 \\
\hline $\begin{array}{l}\text { Avoid continuation of } \\
\text { friendship with infected } \\
\text { person }\end{array}$ & 64 & 42.7 & 108 & 73.0 & 0.00 & 77 & 51.3 & 78 & 52.7 & 0.73 \\
\hline
\end{tabular}

Table 8: Respondents patronage of commercial partner in the last 6 months.

\begin{tabular}{|c|c|c|c|c|c|c|c|c|c|c|}
\hline \multirow{3}{*}{$\begin{array}{l}\text { Patronage of } \\
\text { commercial } \\
\text { partners }\end{array}$} & \multicolumn{4}{|c|}{ Study group } & \multirow{3}{*}{$P<0.05$} & \multicolumn{4}{|c|}{ Control group } & \multirow{3}{*}{$P<0.05$} \\
\hline & \multicolumn{2}{|c|}{$\begin{array}{l}\text { Pre-intervention } \\
(n=150)\end{array}$} & \multicolumn{2}{|c|}{$\begin{array}{l}\text { Post-intervention } \\
(\mathbf{n}=148)\end{array}$} & & \multicolumn{2}{|c|}{$\begin{array}{l}\text { Pre-intervention } \\
(n=150)\end{array}$} & \multicolumn{2}{|c|}{$\begin{array}{l}\text { Post-intervention } \\
(\mathrm{n}=148)\end{array}$} & \\
\hline & Freq & $\%$ & Freq & $\%$ & & Freq & $\%$ & Freq & $\%$ & \\
\hline Yes & 12 & 8.0 & 3 & 2.0 & \multirow{3}{*}{0.018} & 9 & 6.0 & 14 & 9.5 & \multirow{3}{*}{0.23} \\
\hline No & 138 & 92.0 & 145 & 98.0 & & 145 & 94.0 & 134 & 90.5 & \\
\hline Total & 150 & 100 & 148 & 100 & & 150 & 100 & 148 & 100 & \\
\hline
\end{tabular}

\section{DISCUSSION}

Commercial motorcyclists are among the vulnerable groups to HIV/AIDS infection in Nigeria due to the fact that they are male, much younger, abuse substances and have access to disposable incomes, which they often use to engage in high-risk sexual behavior however, they are more likely to change their behavior if they know what to do to avoid the disease. Hence the message "education is the only vaccine against AIDS" that was commonly aired during the early years of efforts to control the epidemic which is also applicable to this group.

The respondents in both study and control groups were similar in their socio-demographic characteristics (as was evidenced by similarity in age group, religion, ethnicity, education and marital status) as well as knowledge and attitude on HIV/AIDS and high risk behaviors before health education intervention. ( $\mathrm{P}>0.05$ i.e. Table 1). All were males with more than two third in the age range of 25-44 years and this age group represents largely, the economically productive segment of the Nigerian society, and also the group at the greatest risk of HIV/AIDS infection. A similar age bracket was observed among motorcycle riders in Songkhla urban area, Thailand. ${ }^{10}$ Following the educational intervention, knowledge on symptoms and methods of prevention as did attitudes to the disease and individuals with the disease. Comparison of responses between baseline and end-line in the intervention group also show remarkable improvement while in control there was no improvement in responses. This improvement is attributed to health education. Similar improvement was also found by other actors in a similar study done among secondary school students. ${ }^{10,11}$

High risky sexual behavior was recorded in this study. Many of the respondents had multiple sexual partners ( $24.7 \%$ in the study and $14.2 \%$ in the control) in the last 6 months before the onset of the study (Table 8). Similar findings was reported in Thailand where six out of ten admit of having sexual partner other than their regular spouse during their life time period and one out of five $(22.7 \%)$ had this practice during the last 6 months and Nigeria. ${ }^{10}$

Higher percentage was observed in a study in Benin, Nigeria where $66 \%$ of commercial motorcyclist studied had multiple sexual partners. ${ }^{5}$ And another study done in North West, Nigeria where $31 \%$ of commercial motorcyclist interviewed had girlfriends. ${ }^{12}$

Post-intervention, number of respondents having multisexual partners decreased from $24.7 \%$ pre-intervention to $14.2 \%$ six months post intervention (Table 8).

The significant difference in sexual behavior in this group of people post-intervention corroborates the earlier studies which showed that theory based behavior change 
interventions can succeed in achieving better results even in the areas of HIV/AIDS prevention and control. ${ }^{13} \mathrm{~A}$ 2005 Nigerian study proposed an integrated model for addressing HIV/AIDS in Sub Saharan Africa. ${ }^{14}$ Within the social context of Africa, the model was based on the convergence of three theories - social learning, diffusion of innovation, and social networks. Researchers can look into this and come up with behavior change interventions that can have more effect on the behavior of commercial motorcyclist.

\section{CONCLUSION}

The findings in this study showed a high level of general awareness about the existence of HIV/AIDS but comprehensive knowledge of HIV/AIDS remains low. Many of the respondents have poor attitudes towards people living with HIV/AIDS. High-risk behaviors that can predispose to HIV/AIDS are still predominant among respondents. However, the study confirms that health education is effective in improving HIV/AIDS knowledge among commercial motorcyclist and also in shaping appropriately their attitudes and high-risk behaviors. Based on the findings in this study, it is hereby recommended that continuous health education programmes and seminars for these people should be organized at by governmental and non-governmental organizations so as to keep them informed and equip them with skills to propagate anti-AIDS message.

Funding: No funding sources Conflict of interest: None declared

Ethical approval: The study was approved by the institutional ethics committee

\section{REFERENCES}

1. UNAIDS. Gender and AIDS almanac. California: UNAIDS; 2001: 17-19, 26-39.

2. Federal Ministry of Health. National HIV seroprevalence sentinel survey among pregnant women attending antenatal clinics in Nigeria. Abuja Nigeria: Federal Ministry of Health; 2010.

3. Federal Republic of Nigeria. Global AIDS response. Country Progress Report. Nigeria: GARPR; 2012.

4. Sule A, Yankaba A, Aisha H, Saadat S. Mutually reenforcing approach as a strategy to HIV prevention among out-of-school youth. Int Conf AIDS. 2002;14:C10813.
5. Adeoye S. Sexual behavior, perception of HIV/AIDS and condom use among commercial motorcyclist in Benin City. Niger Post grad Med J. 2005;12(4):262-5.

6. Sule A, Yankaba A, Aisha H, Saadat S. Mutually reenforcing approach as a strategy to HIV prevention among out-of-school youth. Int Conf AIDS. 2002;14:C10813.

7. Araoye, M, Kayode O, Akande T, Ndom R. Strategies of preventing STDs and AIDS among commercial drivers. Niger Med Pract. 1999;3(8):510 .

8. Owoaje ET, Amoran OE, Osemeikhain O, Ohnoferi OE. Incidence of road traffic accidents and pattern of injury among commercial motorcyclists in a rural community in South-Western Nigeria. J Community Med Primary Health Care. 2005;17(1):7-12.

9. Olawuyi JF (ed). Formula for calculating sample size. In: Olawuyi JF, eds. Biostatistics: A Foundation course in Health Sciences. 1st ed. Ibadan: Toyin Alabi Printing Co.; 1996: 114-115.

10. Somsesta S, Wacharapiuanone S. Knowledge and practice of risk behavior among motorcycle drivers in Sondkhia urban area, Thailand. Int Conf AIDS. 1996 Jul;11:175.

11. Fawole IO, Asuu MC, Oduntan SO, Briger W. A school-based AIDS education programme for secondary school students in Nigeria: a review of effectiveness. Health Educ Res Theory Pract. 1999;14(5):675-83.

12. Isaac WE, Iawali M. Sexual behavior in the AIDS era: are commercial motor cyclists in North West Nigeria at risk of HIV infection. Int Conf Aids. 2004;11(16): 15.

13. Cohen PT, Merle AS, Paul AV. History of HIV in Africa. In: Cohen PT, Merle AS, Paul AV, eds. The AIDS Knowledge Base. 2nd ed. New York: Little Brown \& Co; 1994: 3-17.

14. Obudho R. STDs, HIV, AIDS and Urbanization process in Kenya. Afr J Health Sci. 1995;2(1):20210.

Cite this article as: Olakunle OS, James B, Olusola O, Oluwatoyin O. Outcome of health education on HIV/AIDS knowledge, attitude and risky sexual behavior among commercial motorcyclists in Osogbo, Nigeria. Int J Community Med Public Health 2015;2:596-603. 